\title{
Enhancing the crop yield through capacity building programs: Application of double difference method for evaluation of drip capacity building program in Tamil Nadu State, India
}

\author{
Kuppannan Palanisami ${ }^{1^{*}}$, Coimbatore RamaRao Ranganathan ${ }^{2}$, Devarajulu Sureshkumar ${ }^{2}$, \\ Ravinder Paul Singh Malik ${ }^{3}$

\footnotetext{
${ }^{1}$ International Water Management Institute, Hyderabad, India; ${ }^{*}$ Corresponding Author: K.palanisami@cgiar.org

${ }^{2}$ International Water Management Institute, New Delhi, India

${ }^{3}$ Tamil Nadu Agricultural University, Coimbatore, India
}

Received 28 June 2013; revised 12 December 2013; accepted 23 December 2013

Copyright (C) 2014 Kuppannan Palanisami et al. This is an open access article distributed under the Creative Commons Attribution License, which permits unrestricted use, distribution, and reproduction in any medium, provided the original work is properly cited. In accordance of the Creative Commons Attribution License all Copyrights (c) 2014 are reserved for SCIRP and the owner of the intellectual property Kuppannan Palanisami et al. All Copyright (C 2014 are guarded by law and by SCIRP as a guardian.

\section{ABSTRACT}

A capacity building program on drip irrigation (TNDRIP) was undertaken in certain regions of the Indian State of Tamil Nadu during 2009-2010. An assessment of the impact of the program in terms of effective use of drip irrigation and increased crop yields was made in 2011 by applying double difference method (a combination of both with and without and before and after approaches). The results had indicated that the drip capacity building program resulted in a yield increase of $2.5 \mathrm{t} / \mathrm{ha}$ for Banana 1, $1.9 \mathrm{t} / \mathrm{ha}$ for Banana 2, $3.3 \mathrm{t} / \mathrm{ha}$ for sugarcane and $0.3 \mathrm{t} / \mathrm{ha}$ for turmeric. The conventional method using the before and after situations had shown a yield increase of $4.3 \mathrm{t} / \mathrm{ha}$ for Banana 1, $12.1 \mathrm{t} / \mathrm{ha}$ for Banana 2, 40.6 t/ha for sugarcane and $2.6 \mathrm{t} / \mathrm{ha}$ for turmeric. The conventional approach is highly upward biased in estimating the impact of the drip capacity building program and thus the double difference method will be an appropriate method to evaluate the impact of the programs that involve both with and without as well as before and after situations.

\section{KEYWORDS}

Drip Irrigation; Double Difference Method; Impact Evaluation

\section{INTRODUCTION}

Water is becoming increasingly scarce resource and limiting agricultural development in many developing and developed economies across the world. It is estimated that around 50 percent of the increase in demand for water by the year 2025 can be met by increasing the effective use of irrigation water [1]. In India, almost all the easily possible and economically viable irrigation water potential has already been developed, but the demand for water for different sectors has been growing continuously [2,3]. Moreover, the water use efficiency in the agricultural sector, which still consumes over 80 percent of water, is only in the range of 30 - 40 percent, indicating that there is considerable scope for improving the water use efficiency.

The review of past studies lucidly shows that the solution to the problem of growing water scarcity and persistent water resource degradation across regions is twofold: Firstly, the supply side management practices like watershed development and water resources development through major, medium and minor irrigation projects. The second is through the demand management by efficient use of the available water both in the short-run and long-run perspectives. Recognizing the importance of sustainable water use efficiency in agriculture, a number of demand management strategies (like water pricing, water users association, turnover system etc) have been introduced since the late seventies to increase the water use efficiency especially in the use of surface irrigation water. 
One of the important demand management mechanisms vigorously promoted is the adoption of micro irrigation technologies such as drip and sprinkler methods of irrigation. Many researchers have attempted to study the impact of drip irrigation in improving water use efficiency [4-13]. These studies, by and large, show that the adoption of micro irrigation has produced desired results. The water use efficiency increased up to 100 per cent in a properly designed and managed drip irrigation system $[14,15]$. Drip method of irrigation helps to reduce the over-exploitation of groundwater that partly occurs because of inefficient use of water under surface method of irrigation. Environmental problems associated with the surface method of irrigation like water logging and salinity are also completely absent under drip method of irrigation [5].

In addition, drip method helps in achieving reduction in tillage requirement, higher quality products, increased crop yields and higher fertilizer use efficiency $[7,11,16]$. In addition to the private benefits, the drip irrigation generates substantial social impacts in the forms of enhanced food security, women participation in agriculture (www.ide-india.org) and social status [17]. A recent study indicates that drip irrigation has generated substantial social benefits to the society [18].

Though the potential benefits generated by the drip irrigation method are apparent, the adoption of drip irrigation is yet to be widely promoted across different regions and states in India. Several factors such as huge initial investment, small size of holding, lack of technical support, nature of cropping pattern, access to water and socio-economic conditions of farmers etc., are found to be the major factors influencing adoption of drip irrigation $[11,19]$. In some cases, even after the adoption of drip irrigation, the farmers, particularly, the small farmers have often discontinued the use of drip irrigation for several reasons such as lack of proper maintenance, changes in crop pattern and unreliable water supply [12]. A study in Coimbatore district of Tamil Nadu State found that huge initial investment and small size of holding are the major constraints limiting the adoption of drip technology (100 per cent of farmers), as lack of access to subsidy (46.87 per cent of famers) and lack of technical support for follow up actions (28.85 per cent of farmers) [20].

To minimise dis-adoption rate of drip irrigation by farmers, the International Water Management Institute (IWMI) under its IWMI-TATA Water Policy Program initiated a capacity building program in certain regions of the Indian State of Tamil Nadu. The present paper attempts to make an assessment of the impact of the capacity development program mainly on use of drip irrigation in improving crop yields.

Hypotheses: The following hypotheses were tested in this study.

- Drip capacity building will enhance the yield of crops compared to drip irrigation alone.

- Appropriate evaluation methods will capture exactly the impact of the capacity building program.

\section{CAPACITY BUILDING PROGRAM ON DRIP IRRIGATION}

Realising the significance of drip maintenance practices, drip irrigation capacity building and management initiative for maximizing productivity and income (TNDRIP) was conceived and implemented by International Water Management Institute (IWMI) under the IWMI-TATA water policy program jointly with the Water Technology Centre (WTC) of the Tamil Nadu Agricultural University (TNAU) and Jain Irrigation Systems Limited (JISL) in Coimbatore district, Tamil Nadu state, Indiaduring 2009-2010. The objective of TNDRIP is to sustain the drip irrigation through increased adoption and proper drip maintenance practices by the farmers in order to achieve increased crop yields.

The program was implemented in 100 villages covering about 1000 farmers who have adopted the drip irrigation already for various crops.A base line survey was conducted to know the current level of use of drip irrigation, inputs used and crop yields. The main part of the capacity building program was one day training which was organized in each village where farmers with different crops and farm sizes actively participated. The field based training was given by the field technicians of the WTC and JISL through lectures, hand-on exercises with the drip systems, demonstrations of the various drip materials and question-answer sessions.

The contents of the training mainly focused on the operation and maintenance practices of drip irrigation system besides fertigation and irrigation scheduling practices. In addition, the farmers were given hand outs and booklets (in local language) regarding fertigation, drip demonstrationsand cleaning (sand filters, PVC pipes (sub-mains and laterals, screens and disc filters) drip system using acid. This helped the farmers in a big way to learn the drip and fertigation technologies and their periodical maintenance.

\section{METHODOLOGY}

\subsection{Impact of Technology on Crop Yield and the Evaluation of the Technology Impact}

Technology is nothing but the application of improved knowledge on production relationships and thus technology has the effect of raising the production function. More output per unit of input (water) is possible with the new technology such as drip irrigation. This indicates that production can be increased with improved technology through the same amount of inputs that were used with traditional technology or the current production 
level can be reached with fewer inputs with improved technology. Consider the Figure 1, where curve AA refers the traditional irrigation technology production function, curve $A B$ refers the improved (drip) technology production function and curve AC refers the improved drip technology with capacity building. With $\mathrm{X}$ units of water, traditional technology produces $\mathrm{Y}_{1}$ units of output, improved (drip) technology produces $Y_{2}$ units of output where as improved technology with capacity building produces $\mathrm{Y}_{3}$ units of output. The difference between $\mathrm{Y}_{2}$ and $Y_{3}$ is the additional output due to capacity building.

\subsection{Impact Evaluation Using Double-Difference Method}

Several tools or approaches are used for impact evaluation. The most commonly used tools are the financial measures like the benefit-cost (B-C) ratio and internal rate of return (IRR) [11,19,21,22]. The major problems with this approach is that the benefits and costs are calculated using either before and after or with and without concept which ignores some of the benefits that are considered as residual which may occur even without the intervention such as drip irrigation. Hence an approach that considers both with and without as well as before and after situations is important.

The approach of any analysis of impact can be accomplished into two ways. Firstly, "with project” parameters compared to the "pre-project" situation gives the incremental benefits due to the project. But these increments in the parameters intrinsically include the changes due to state of art of technology. Thus sometimes, the benefits may be exaggerated. Secondly, the literature on project analysis unanimously suggests the use of comparison between the "project parameters" with the "non-project

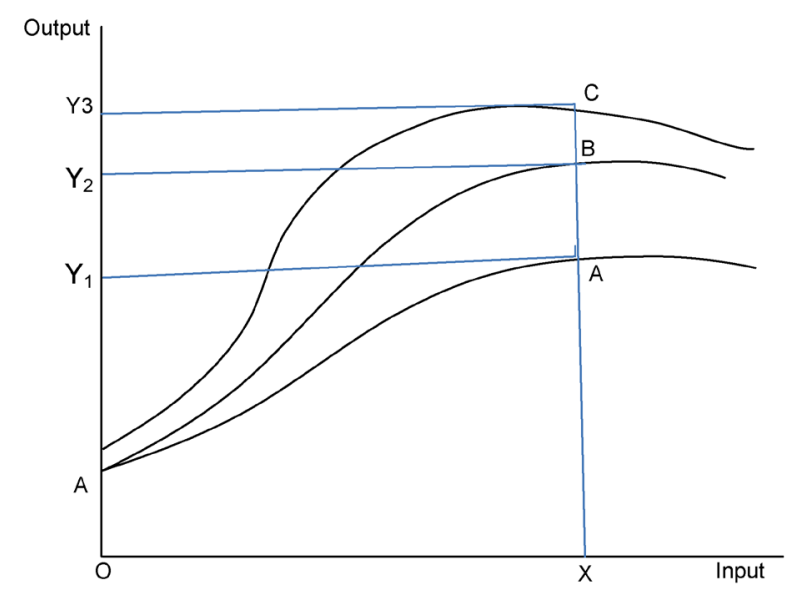

Figure 1. Technology adoption and crop yield. Note: AA refers the production function with traditional irrigation technology, $\mathrm{AB}$ refers the production function with improved (drip) technology; AC refers the production function with improved (drip) technology along with capacity building. control region'. This method automatically incorporates the correction for the impact of technology in the absence of the project. For the present study, the information were collected for the pre and post-project period and compared with the control as well. Hence, the approach is a combination of both with and without and before and after approaches i.e. double difference method (Table 1).

Farm level data were collected from both types of drip farmers i.e. who have participated in the capacity building program and who have not participated. This enables the use of the double difference method to study the impact of the drip capacity building program. The framework was adopted from the program evaluation literature [23,24].

The resulting measures can be interpreted as the expected effect of implementing the drip capacity building program. The columns distinguish between groups with and without the program and the rows distinguish between before and after the program. Before the capacity building program, one would expect the average yield of different crops be similar for the two groups, so that the quantity (D0 - C0) would be close to zero. Once the capacity building program has been implemented, however, one would expect differences between the groups as a result of the improvement in knowledge of the farmers about the drip maintenance, fertigation and irrigation scheduling due to the program. The impact of the program, however, would be better assessed considering any pre-existing observable or unobservable differences between the two randomly assigned groups i.e. the doubledifference estimate, which is obtained by subtracting the preexisting differences between the groups, (D0 - C0), from the difference after the program has been implemented, (D1 - C1) [23]. This is best explained in Figure 2.

Double Difference (DD) methodology is becoming a popular tool for studying the impact analysis as it has the advantage to control for the time-invariant characteristics of farmers when comparing adopters and non-adopters of a technology or a capacity building program. In this methodology, the average impact of a capacity building program is computed by the formula

Table 1. Double difference method of impact assessment of drip capacity building.

\begin{tabular}{cccc}
\hline Particulars & $\begin{array}{c}\text { Drip } \\
\text { Participants }\end{array}$ & Non-participants & $\begin{array}{c}\text { Difference across } \\
\text { groups }\end{array}$ \\
\hline $\begin{array}{c}\text { After drip } \\
\text { training }\end{array}$ & D1 & C1 & D1 - C1 \\
$\begin{array}{c}\text { Before drip } \\
\text { training }\end{array}$ & D0 & C0 & D0 - C0 \\
$\begin{array}{c}\text { Difference } \\
\text { across time }\end{array}$ & D1-D0 & C1-C0 & $\begin{array}{c}\text { Double difference } \\
\text { (D1 - C1)-(D0 - C0) }\end{array}$ \\
\hline
\end{tabular}




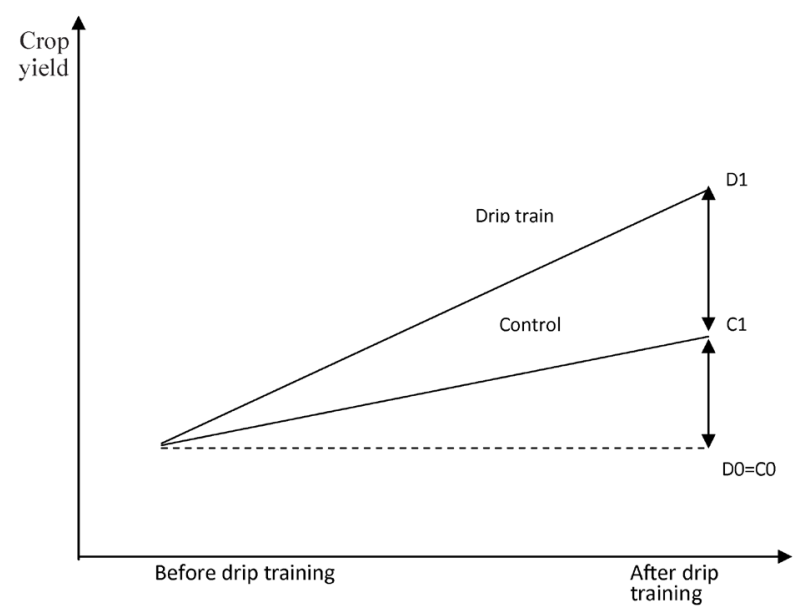

Figure 2. Illustration of impact of capacity building program by double difference method.

$$
\begin{aligned}
& \text { Double Difference(DD) } \\
& =E\left(Y_{1}^{T}-Y_{0}^{T} \mid T_{1}=1\right)-E\left(Y_{1}^{c}-Y_{0}^{c} \mid T_{1}=0\right)
\end{aligned}
$$

where $Y_{t}^{T}$ and $Y_{t}^{C}$ respectively denote the outcome responses for the trained and control groups at period $t(=0,1)$ where the time period $t=0$ corresponds to the period before program implementation and the period $\mathrm{t}=$ 1 corresponds to after program implementation. Further, $\mathrm{T}_{1}=1$ means presence of the program at time $\mathrm{t}=1$ and $\mathrm{T}_{1}=0$ means absence of the program. The first term in Equation (1) represents the average difference between before-after for the trained group and hence it is given by

$$
E\left(Y_{1}^{T}-Y_{0}^{T} \mid T_{1}=1\right)=\frac{1}{N_{T}} \sum_{i \varepsilon T}\left(Y_{i 1}-Y_{i 0}\right)=\bar{y}_{T 1}-\bar{y}_{T 0}
$$

Similarly for the control group, the second term is given by

$$
E\left(Y_{1}^{c}-Y_{0}^{c} \mid T_{1}=0\right)=\frac{1}{N_{c}} \sum_{j \varepsilon c}\left(Y_{j 1}-Y_{j 0}\right)=\bar{y}_{c 1}-\bar{y}_{c 0}
$$

Substituting these values in (1), the impact of the program can be obtained as

$$
\text { Impact }=\left(\bar{y}_{T 1}-\bar{y}_{T 0}\right)-\left(\bar{y}_{c 1}-\bar{y}_{c 0}\right)
$$

The same results can be obtained by following a regression approach as follows:

For each observation $i$, let us define a variable $\delta_{i}$ as $\delta_{i}=0$ if the observation is from the control group and $\delta_{i}=1$ if it is from the trainedgroup. Similarly for each observation $i$ define a variable $T_{i}$ as $T_{i}=0$ if the observation belongs to time $t=0$, that is before the drip capacity building program and $T_{i}=1$ if the observation belongs to time $t=1$, that is, after the program. Now form the regression equation,

$$
y_{i}=a+b \delta_{i}+c T_{i}+d \delta_{i} T_{i}
$$

The following results can be easily checked:

\begin{tabular}{cccc}
\hline Observation belongs to & $\delta$ & $T$ & $y_{i}$ \\
\hline Control group before the program & 0 & 0 & $\bar{y}_{C 0}=a$ \\
Control group after the program & 0 & 1 & $\bar{y}_{C 1}=a+c$ \\
Trained group before the program & 1 & 0 & $\bar{y}_{T 0}=a+b$ \\
Trained group after the program & 1 & 1 & $\bar{y}_{T 1}=a+b+c+d$ \\
\hline
\end{tabular}

So using Equation (4)

Impact of the program

$=((a+b+c+d)-(a+b))-((a+c)-a)=d$

\section{DATA AND VARIABLES}

Out of the targeted 1000 farmers for the training, only 800 farmers actively participated in the training. Out of this, 500 farmers were selected employing random sampling procedure to study the impact of the TNDRIP during November 2011, one year after the program was introduced. In order to make a comparative study, 250 drip farmers in these villages who have not participated in the capacity building program were selected as control. Thus, a sample of 750 farmers was covered for the impact study. The needed information from the respondents was gathered personally administering the interview schedule. The primary information collected from the farmers included mainly the farm size, cost of wells, cost of drip irrigation system, crops grown, maintenandce costs, groundwater use, crop production including inputs used and crop yields, adoption of drip irrigation practices and the constraints in using the drip irrigation. In addition, the details of the trainings attended and subject matter learnt during the training program were collected from the respondents.The base line data collected in 2009 wasalso used for cross checking the inputs used and crop yields of the farmers prior to training.

\section{RESULTS AND DISCUSSIONS}

\subsection{General Characteristics of the Farm Households}

Knowledge on general profile of the sample respondents will help us to understand better the impact of the capacity building program. The general characteristics in terms of landholdings, cropped area, and irrigated area for the participants of the drip capacity building program were compared with that of control farmers. The average size of holding of the drip-farmers with training was significantly high as compared to control farmers. The results had shown that mostly large farmers had attended the capacity building program compared to small and marginal farmers who have not shown much interest due to their limited area under drip irrigation and hence the 
average farm size was comparatively high under participants of the drip training. However, cropping intensity and irrigation intensity are more or less same among the participants of drip training and control farmers (Table 2).

\subsection{Awareness and Adoption of Drip Maintenance}

The capacity building program has created adequate awareness about various drip management practices. The perception of the trainees about the important drip management and maintenance activities before their partici- pation in the training revealed that most of them were aware about the fertigation practice (48\%) followed by the cleaning of screen/disc filters (42.7\%). Many farmers (5\% to $21 \%$ ) were aware about the practices like cleaning the sub-mains and laterals, acid treatment, protecting the drip system, valve protection and placing the laterals under shade. However, no one was aware about the important practices like cleaning the sand filter, pressure regulation in the laterals and irrigation scheduling to various crops before attending the training program (Table 3).

After undergoing the training program all the trainees

Table 2. General characteristics of the sample farmers.

\begin{tabular}{|c|c|c|}
\hline Particulars & Participants of drip training $(\mathrm{N}=500)$ & Control $(\mathrm{N}=250)$ \\
\hline Average farm size (ha) & $3.41^{* * *}$ & 2.58 \\
\hline Net sown area (ha) & $3.31^{* * *}$ & 2.43 \\
\hline Gross cropped area (ha) & $3.86^{* * *}$ & 2.79 \\
\hline Cropping intensity (\%) ${ }^{\mathrm{a}}$ & $116.6^{* * *}$ & 114.8 \\
\hline Net irrigated area (ha) & $2.97^{* * *}$ & 2.18 \\
\hline Gross irrigated area (ha) & $3.26^{* * *}$ & 2.38 \\
\hline Irrigation intensity (\%) ${ }^{\mathrm{b}}$ & $109.8^{* * *}$ & 109.2 \\
\hline Percentage of area irrigated by wells to the total cropped area (\%) & 84.5 & 85.3 \\
\hline Percentage of area irrigated under drip to gross cropped area (\%) & 67.1 & 64.8 \\
\hline Percentage of area irrigated under drip to gross irrigated area (\%) & 79.5 & 75.9 \\
\hline
\end{tabular}

Source: Field survey. Notes: ${ }^{* * *}$ indicates values are significantly different at 1 per cent levels from the corresponding values of control farmers. ${ }^{\text {a } C r o p p i n g ~}$ intensity is defined as the ratio of gross cropped area to net sown area and is expressed as a percentage; ${ }^{\mathrm{b}}$ Irrigation intensity is the ratio of gross irrigated area to net irrigated area and is expressed as a percentage.

Tab le 3. Impact of capacity building on farmers' awareness and adoption of various practices.

\begin{tabular}{|c|c|c|c|c|}
\hline \multirow{2}{*}{ Particulars } & \multicolumn{2}{|c|}{ Awareness Before training* } & \multicolumn{2}{|c|}{ Awareness \& Adoption After training } \\
\hline & No.of farmers & Percentage & No.of farmers & Percentage \\
\hline Cleaning screen/disc filter & 64 & 42.7 & 86 & 57.3 \\
\hline Cleaning sand filter & .. & .. & 50 & 33.3 \\
\hline Cleaning sub-main & 22 & 14.7 & 128 & 85.3 \\
\hline Cleaning laterals & 22 & 14.7 & 128 & 85.3 \\
\hline Acid treatment & 10 & 6.7 & 140 & 93.3 \\
\hline Pressure regulation & .. & .. & 150 & 100.0 \\
\hline Thatching the drip system & 32 & 21.3 & 118 & 78.7 \\
\hline Laterals in shade & 8 & 5.33 & 142 & 94.7 \\
\hline Irrigation scheduling & .. & .. & 150 & 100.0 \\
\hline
\end{tabular}

*Most of the farmers were aware of these practices when the system was installed in their farms; subsequently due to lack of skills and knowledge in handling these practices, most of the farmers were not adopting these practices properly. Source: survey. 
were aware about all the important practices and started adopting them. Hence, it could be inferred that the TNDRIP training has remained as the only source to provide first hand information and created awareness about the maintenance practices such as pressure regulation, irrigation scheduling, acid treatment and advantages of placing the laterals under shade. However, only onethird of the trainees were aware of the practice of cleaning the sand filter even after undergoing the training. The overall picture had indicated that the TNDRIP training has made significant impact among farmers in adopting the drip maintenance practices in a better manner than before.

\subsection{Benefits Perceived by the Farmers Due to the Adoption}

The adopters of drip maintenance practices were enquired about the overall benefits they perceived due to the adoption of the drip maintenance practices in their farm. They were asked to rank their responses. The adopted farmers had altogether perceived and ranked six benefits due to the adoption of the maintenance practices taught in the training (Table 4). Among these, the top three benefits that were perceived and ranked were the reduction in the duration of irrigation, improved dripper discharge and achievement of uniform distribution of water in the field.

$$
\text { Percent Position }=100\left(R_{i j}-0.5\right) / N_{j}
$$

where,

$R_{i j}=$ Rank given for the $\mathrm{i}^{\text {th }}$ factor by the $\mathrm{j}^{\text {th }}$ respondent, and

$N_{j}=$ Number of factors ranked by the $\mathrm{j}^{\text {th }}$ respondent.

The benefit namely, uniform growth of plants in the field was perceived and ranked as fourth by the adopters. All these four benefits were interlinked due to the better maintenance practices adopted by the farmers.

The fact that was endorsed by majority of the adopters was that there was reduction in the duration of irrigation

Table 4. Farmers' perception about the benefits due to drip maintenance.

\begin{tabular}{ccc}
\hline Benefits & Garret score $^{*}$ & Rank \\
\hline Reduction in the duration of irrigation & 63 & I \\
Improved dripper discharge & 59 & II \\
Uniform distribution of water in field & 56 & III \\
Uniform growth of plants in field & 51 & IV \\
Improvement in yield & 49 & V \\
Extended life of drip system & 39 & VI \\
\hline
\end{tabular}

* Garret scores [25], were worked out using the following formula. to an extent of up to 30 per cent than it was observed without the adoption of the maintenance practices. Hence this particular benefit was ranked as first by the adopters. The regular cleaning and maintenance of filters, submains and laterals might have rendered free flow of water through the drip system effectively. The adopters used pressure gauge to regulate the pressure in the sub-mains and laterals as per the recommendations. This particular action had resulted in ensuring uniform distribution of water throughout the field thus promoting uniform growth of plants also. These benefits were observable and hence most of the farmers had perceived such benefits.

The other two benefits that were perceived and ranked in the last order by the adopters were improvement in yield of crops and extended life expected over the drip system due to adoption of regular maintenance practices. The adopters had recorded an increase in yield up to 10 per cent across various crops. Although this change in yield is negligible, it has been perceived by some farmers and hence ranked fifth. Anticipation over the extended life of the drip system was perceived and ranked last as it was not observed by the adopters but still they believed the benefit.

Sharing or recommending the learnt technologies to peers is considered as a social impact indicator of the TNDRIP project. Hence the information sharing behavior of the farmers was studied. Of the total number of 500 farmers studied, 70 per cent of the farmers shared their information to others and 30 per cent farmers have not shared their information. Among the farmers shared their information, 52.38 per cent of farmers had shared to their own family members and the remaining 47.62 per cent of farmers shared to other fellow farmers. This showed that the penetration of the drip fertigation technologies, their maintenance and management will be possible through capacity building programs.

\subsection{Impact of Capacity Building Program}

Here our aim is to examine whether the capacity building program has generated any impact on yield of crops. The capacity building program not only created adequate knowledge on drip maintenance activities but also on irrigation scheduling and fertigation which would help to increase crop productivity. The details of the mean yield of crops under different farmer samples had indicated that crop yields were comparatively high for farmers who were trained in drip system operation and maintenance (Table 5).

In the present study, the double difference method of impact assessment was employed to assess the impact due to the capacity building program on crop yield (Table 6). The two types of respondents were compared and assessed the net impacts due to capacity building pro- 
Tab le 5. Crop yields under different farmer samples.

\begin{tabular}{|c|c|c|c|c|c|c|}
\hline Crops & Type of samples & Number offarmers & Mean yield (t/ha) & Minimum yield (t/ha) & Maximum yield (t/ha) & Std Dev. \\
\hline \multirow[t]{4}{*}{ Banana 1} & Control-Before & 172 & 45.9 & 37.1 & 57.3 & 3.8 \\
\hline & Control-After & 172 & 47.7 & 38.5 & 66.7 & 4.6 \\
\hline & Trained-Before & 172 & 65.2 & 55.6 & 85.0 & 3.6 \\
\hline & Trained-After & 172 & 69.6 & 55.3 & 94.2 & 4.6 \\
\hline \multirow[t]{4}{*}{ Banana 2} & Control-Before & 93 & 22.3 & 17.3 & 59.3 & 4.4 \\
\hline & Control-After & 93 & 25.0 & 18.0 & 31.9 & 24.2 \\
\hline & Trained-Before & 93 & 32.5 & 29.1 & 79.0 & 5.2 \\
\hline & Trained-After & 93 & 37.1 & 29.9 & 42.4 & 10.0 \\
\hline \multirow[t]{4}{*}{ Sugarcane } & Control-Before & 198 & 116.3 & 98.8 & 143.3 & 10.3 \\
\hline & Control-After & 198 & 120.0 & 98.8 & 145.7 & 9.9 \\
\hline & Trained-Before & 198 & 153.6 & 123.5 & 182.8 & 15.2 \\
\hline & Trained-After & 198 & 160.3 & 130.9 & 192.7 & 15.5 \\
\hline \multirow[t]{4}{*}{ Turmeric } & Control-Before & 91 & 6.3 & 5.2 & 8.3 & 0.8 \\
\hline & Control-After & 91 & 6.4 & 5.2 & 9.4 & 0.9 \\
\hline & Trained-Before & 91 & 8.7 & 6.9 & 11.4 & 1.4 \\
\hline & Trained-After & 91 & 9.0 & 7.1 & 13.6 & 1.4 \\
\hline
\end{tabular}

Note: Banana-1: Variety robusta; Banana-2: Variety Nendran.

Tab le 6. Impact of capacity building intervention in drip irrigation.

\begin{tabular}{|c|c|c|c|c|}
\hline Observation belongs to & Banana 1 & Banana 2 & Sugarcane & Turmeric \\
\hline Control group before the program (a) & 45.9 & 22.3 & 116.4 & 6.3 \\
\hline Control group after the program $(a+c)$ & 47.7 & 32.5 & 153.6 & 8.7 \\
\hline Trained group before the program $(\mathrm{a}+\mathrm{b})$ & 65.3 & 25.0 & 119.9 & 6.4 \\
\hline Trained group after the program $(a+b+c+d)$ & 69.6 & 37.1 & 160.5 & 9.0 \\
\hline Net impact due to capacity building intervention (=d) & 2.5 & 1.8 & 3.3 & 0.3 \\
\hline
\end{tabular}

gram. For instance, the yield of banana 1 was 45.9 t/ha for the control farmers before the training period. The yield of Banana 1 for the same set of farmers after the training period was $47.7 \mathrm{t} / \mathrm{ha}$, thus the increase in yield of Banana 1 even among the farmers who have not participated in the capacity building program was $1.8 \mathrm{t} / \mathrm{ha}$.

This increase in yield might be due to the experience, cumulative knowledge gained by the farmers, use of better quality of inputs, technological growth and so on. Similarly, the above yields for the trained farmers (i.e. farmers who have participated in the capacity building program) were $65.3 \mathrm{t} / \mathrm{ha}$ and $69.6 \mathrm{t} / \mathrm{ha}$ respectively, leading to a difference of $4.3 \mathrm{t} / \mathrm{ha}$. However, our interest here is to assess mainly the yield increase attributed to the capacity building program. The double difference method captured this yield increase as 2.5 t/ha (i.e. 4.3t/ha - 1.8t/ha). Similarly, the yield increase due to the training was calculated for other crops as shown in Table 6 .

The results of the double-difference method using the regression analysis are presented in Table 7 It is seen that the drip capacity building program had significant impact on yield of crops such as Banana 1 and sugarcane. The technological growth indicated by time (T) had significant impact on crop yield in all the crops as evident from the coefficients of " $T$ " which were significant for all crops.

For instance, the results of Banana 1 estimates had shown interesting results. The adjusted $\mathrm{R}^{2}$ is worked out to 0.86 indicating 86 per cent of the variations were explained by the explanatory variables. The intercept term indicated the mean yield of the control farmers i.e. the yield of control farmers. It is evident that there is signifi- 
Table 7. Results of the regression analysis on impact of capacity building program on crop yield.

\begin{tabular}{|c|c|c|c|c|c|}
\hline Crops & Constant & $\delta$ & $\mathrm{T}$ & $\delta \mathrm{T}$ & Adjusted R-Squared \\
\hline \multirow[t]{2}{*}{ Banana 1} & 45.887 & $19.366^{* * *}$ & $1.847^{* * *}$ & $2.542^{* * *}$ & 0.86 \\
\hline & $(144.75)$ & (43.19) & $(4.12)$ & $(4.01)$ & \\
\hline \multirow[t]{2}{*}{ Banana 2} & 22.274 & 2.750 & $10.267^{* * *}$ & 1.767 & 0.15 \\
\hline & (15.88) & (1.387) & (5.178) & $(0.630)$ & \\
\hline \multirow[t]{2}{*}{ Sugarcane } & 116.404 & $3.574^{* * *}$ & $37.219^{* * *}$ & $3.285^{*}$ & 0.69 \\
\hline & $(126.24)$ & (2.74) & (28.54) & $(1.78)$ & \\
\hline \multirow[t]{2}{*}{ Turmeric } & 6.298 & 0.119 & $2.365^{* * *}$ & 0.265 & 0.53 \\
\hline & (51.04) & $(0.68)$ & (13.55) & (1.07) & \\
\hline
\end{tabular}

Note: Figures in parentheses indicate estimated “t” ratios. ${ }^{* * *}$ Significant at $1 \%$ level; ${ }^{*}$ Significant at $10 \%$ level.

cant difference between yield of trained andcontrol farmers in the base period. Similarly, there is a significant increase in yield due to time period among the control farmers. It is evident that $1.8 \mathrm{t} / \mathrm{ha}$ increase in yield was realised over time period among the control farmers. The impact of capacity building programwas significant on the expected positive line which showed that the capacity building programalone has increased the crop yield by $2.5 \mathrm{t} / \mathrm{ha}$.

\subsection{Novelty and Merit of the Double Difference Method}

The novelty of the double difference method is that it is simple and appropriate method in capturing the yield increase due to capacity building program alone. The double difference method has estimated the impact of the drip capacity building program interms of yield increase as $2.5 \mathrm{t} /$ ha for Banana 1, $1.9 \mathrm{t} / \mathrm{ha}$ for Banana 2, $3.3 \mathrm{t} / \mathrm{ha}$ for sugarcane and $0.3 \mathrm{t} / \mathrm{ha}$ for turmeric. In the absence of the double difference method, the impact of the drip capacity building program interms of yield increase was $4.3 \mathrm{t} /$ ha for Banana 1, $12.1 \mathrm{t} /$ ha for Banana 2, $40.6 \mathrm{t} / \mathrm{ha}$ for sugarcane and 2.6 t/ha for turmeric (Table 8 and Figure 3). Thus the conventional approach is highly upward biased by over-estimating the impact of the capacity building program. Thus the merit of the double difference method is very clear from the results of the analysis. The results further confirmed the hypotheses that drip capacity building will increase the crop yield and the use of appropriate quantification method (double difference method) will capture the exact impact of the capacity building program.

The results of the double difference method could further enhance the richness of measurement methodologies in impact evaluation. Hence future impact studies could find this an interesting and valuable tool in impact evaluation of the technologies where time period is a major

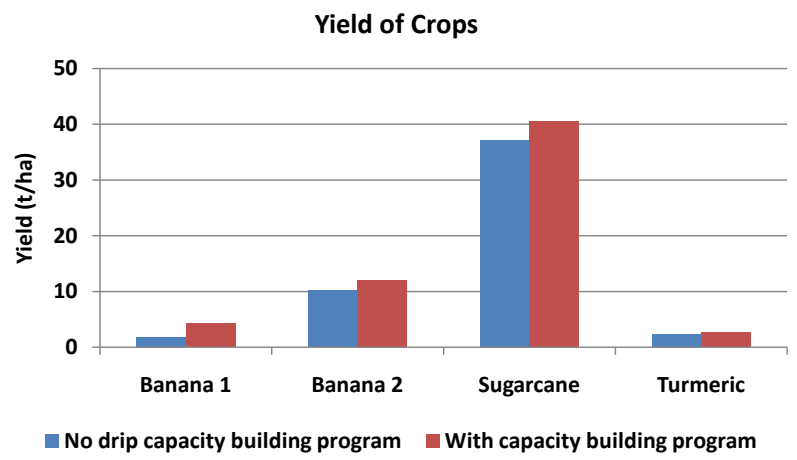

Figure 3. Impact of drip capacity building program on crop yield.

player along with the technologies. For example, in several cases, farmers could be able to increase their crop yield over time due to better management. Thus the approach could help in decomposing the yield increase due to capacity building intervention and time period (management) as well.

\subsection{Constraints in Adoption of Drip Maintenance Activities}

During the survey it was found that there are several factors that limited the adoption of maintenance practices. One of the constraints for adoption of the maintenance practices was the insufficient knowledge about the relevance of pressure regulation in the drip irrigation system. Farmers were not aware about the use of pressure gauge in the laterals to maintain uniform pressure so that the water would flow through the system effectively. The farmers believed that use of Hydro Chloric $(\mathrm{HCl})$ acid treatment in the drip system would affect the soil health and crop growth and hence feared to adopt the acid treatment technology for removing the blockage/salt encrustation in the drip system. Most of the farmers also felt that they were ignorant about the maintenance pack- 
age to be adopted for the drip system which acted as one of the constraints for its adoption. Hence the lack of knowledge and understanding of the farmers about the drip and its maintenance practices itself remained as constraints for its adoption (Table 9).

Farmers were asked to express the factors that remained as constraints to the adoption of the maintenance practices. The findings revealed that a majority of the trained farmers (80\%) expressed high cost of the water soluble fertilizers as the major constraint. About half of them revealed that non-availability of pressure gauge was one of the constraints.

It is a fact that pressure gauge apparatus was not sold commonly in the shops located in rural/town areas. This was perceived as one of the reasons for non-adoption of the maintenance practices. Some farmers (12\%) were reluctant to invest on the venturi unit which is needed for the adoption of the fertigation and acid treatment as well. About 41 per cent of them stated the non-availability of water soluble fertilizers in the local village/town market remained as one of the reasons for non-adoption of fertigation practice even though they had been supplied with the fertilizer tank on subsidy basis by the Government of Tamil Nadu. One-fourth of the farmers (24\%) expected the assistance of the extension or development staff to adopt acid treatment technology in their farms as they were not very confident in adopting the technology on their own. These constraints need to be addressed in the future training programs.

\section{CONCLUSIONS AND RECOMMENDATIONS}

TNDRIP training has brought out significant impact among farmers to adopt the drip maintenance practices in varied proportions. Practices such as cleaning the filters, sub-mains and laterals, pressure regulation, acid treatment, thatching the drip system, placing the laterals in shade etc. were adopted by a majority of the trainees as a result of their participation in the training. The study revealed that a majority of the farmers (70\%) had shared the information about the drip maintenance practices to their family members and other fellow farmers.

It is found that the drip capacity building program has produced significant impact on yield of crops such as banana and sugarcane. Drip farmers with training has increased their crop yield by $138 \%$ under Banana 1, 19\% under Banana 2, 9\% under sugarcane and 13\% under turmeric crops indicating that compared to drip irrigation alone, drip with capacity building helped them to exploit the full potential of drip irrigation. Compared to the cost of the training (Rs 110/ha), the additional yield has resulted in an additional per ha gross margin of Rs. 14,000, Rs. 32,015, Rs. 1650, and Rs. 14,893 per year respectively under Banana 1, Banana 2, Sugarcane and turmeric. Given this cost effectiveness of the capacity building program, it is suggested to introduce more number of drip capacity building programs across regions so as to achieve more crop per drop of water. The development departments such as Department of Agriculture, Horticulture, and Agricultural Engineering may be geared up to follow up with similar kind of capacity building programs across the regions. This will further have multiplier impact in terms of bringing new farmers under drip irrigation as well as effective use of fertilizers. By establishing such training programs in the rural areas, local expertise in terms of entrepreneur development through public private partnership can also be developed.

Tab le 8. Comparison of crop yields under drip and drip with capacity building.

\begin{tabular}{cccc}
\hline Crops & $\begin{array}{c}\text { Increase in yield of drip farmers } \\
\text { without training (t/ha) }\end{array}$ & $\begin{array}{c}\text { Increase in yield of drip farmers } \\
\text { with training (t/ha) }\end{array}$ & $\begin{array}{c}\text { Increase in yield due to training } \\
\text { alone }(\mathrm{t} / \mathrm{ha})\end{array}$ \\
\hline Banana 1 & 1.8 & 4.3 & 2.5 \\
Banana 2 & 10.3 & 12.1 & 1.8 \\
Sugarcane & 37.2 & 40.5 & 3.3 \\
Turmeric & 2.4 & 2.7 & 0.3 \\
\hline
\end{tabular}

Table 9. Constraints in adoption of the drip maintenance activities.

\begin{tabular}{ccc}
\hline Before attending the training & Per cent of farmers & After attending the training \\
\hline Insufficient knowledge about pressure maintenance & 94.70 & High cost of water soluble fertilizers \\
Fear of acid treatment & 90.00 & Non-availability of pressure gauge \\
Rack of technical knowhow of maintenance practices \\
$\begin{array}{c}\text { Misunderstanding of farmers about } \\
\text { drip irrigation technology }\end{array}$ & 89.30 & $\begin{array}{c}\text { Reluctance to invest on venturi } \\
\text { Non-availability of water soluble } \\
\text { fertilizers locally } \\
\text { Lack of confidence to use } \\
\text { correct concentration of acid }\end{array}$ \\
\hline
\end{tabular}




\section{ACKNOWLEDGEMENTS}

This study was conducted under the IWMI-Tata Water Policy Program supported by International Water Management Institute (IWMI) and Sir Ratan Tata Trust (SRTT). We acknowledge the support provided by our project partners, Dr S. Chellamuthu, Director and Dr C. Mayilswami, Professor of the Water Technology Centre of Tamil Nadu Agricultural University and Dr S. Narayanan, Vice President of the Jain Irrigation Systems, Coimbatore.

\section{REFERENCES}

[1] Seckler, D., Molden, U.A.D., de Silva, R. and Barker, R. (1998) World water demand and supply, 1990 to 2025: Scenarios and Issues. Research Report 19, International Water Management Institute (IWMI), Colombo, Sri Lanka.

[2] Saleth, R.M. (1996) Water institutions in India: Economics, law and policy. Commonwealth Publishers, New Delhi.

[3] Vaidyanathan, A. (1999) Water resources management: Institutions and irrigation development in India. Oxford University Press, New Delhi.

[4] Magar, S.S., Firke, N.N. and Kadam, J.R. (1988) Importance of drip irrigation. Sinchan, 7, 61-62.

[5] Narayanamoorthy, A. (1997) Drip irrigation: A viable option for future irrigation development. Productivity, 38, 504-511.

[6] Cuykendall, C.H., White, G.B., Shaffer, B.E., Lakso, A.N. and Dunst, R.M. (1999) Economics of drip irrigation for juice grape vineyards in New York State. Department of Agricultural, Resource and Managerial Economic. College of Agriculture and Life Sciences, Cornell University, Ithaca, New York, 14853-17801.

[7] Qureshi, M.E, Wegener, M.K. Harrison, S.R. and Bristow, K.L. (2001). Economic evaluation of alternate irrigation systems for sugarcane in the burdekin delta in North Queensland, Australia. In: Brebbia,C.A., Anagnostopoulos, K, Katsifarakis, K. and Cheng, A.H.D. Eds., Water Resource Management, WIT Press, Boston, 47-57.

[8] Dhawan, B.D. (2002) Technological change in irrigated agriculture: A study of water saving methods. Commonwealth Publishers, New Delhi.

[9] Narayanamoorthy, A. (2003) Averting water crisis by drip method of irrigation: A study of two water intensive crops. Indian Journal of Agricultural Economics, 58, 427-437.

[10] Verma, S., Tsephal, S. and Jose, T. (2004) Pepsee systems: Grass root innovation under groundwater stress. Water Policy, 6, 1-16.

[11] Namara, R.E., Upadhyay, B. and Nagar, R.K. (2005) Adoption and impacts of microirrigation technologies: Empirical results from selected localities of Maharashtra and Gujarat States of India. Research Report 93, International Water Management Institute, Colombo, Sri Lanka.

[12] Kulecho, I.K and Weatherhead. E.K. (2005) Reasons for smallholder farmers discontinuing with low cost micro ir- rigation: A case study from Kenya. Irrigation and Drainage Systems, 19, 179-188.

[13] Suresh Kumar, D. and Palanisami, K. (2010) Impact of drip irrigation on farming system: Evidences from Southern India. Agricultural Economics Research Review, 23, 265-272.

[14] Indian National Committee on Irrigation and Drainage (INCID). (1994) Drip irrigation in India, New Delhi.

[15] Sivanappan, R.K. (1994) Prospects of micro-irrigation in India. Irrigation and Drainage Systems, 8, 49-58.

[16] Sivanappan, R.K. (2002) Strengths and weaknesses of growth of drip irrigation in India. Proceedings of the GOI Short Term Training on Micro Irrigation for Sustainable Agriculture, 19-21 June 2002, Water Technology Centre, Tamil Nadu Agricultural University, Coimbatore.

[17] Shah, T., Verma, S., Bhamoriya, V., Ghosh, S. and Sakthivadivel, R. (2005) Social impact of technical innovations: Study of organic cotton and low cost drip irrigation in the agrarian economy of west Nimar. Region. International Development Enterprises (India), Delhi. http://www.ide-india.org/ide/socialimpact.shtml

[18] Suresh Kumar, D. and Palanisami, K. (2011) Can drip irrigation technology be socially beneficial? Evidence from Southern India. Water Policy, 13, 571-587. http://dx.doi.org/10.2166/wp.2010.311

[19] Suresh Kumar, D. (2012) An analysis of economics of adoption of drip irrigation: Some experiences and evidences. The Bangladesh Development Studies, (In Press).

[20] Suresh Kumar, D. (2008) Promoting drip irrigation: Where and why? Managing water in the face of growing scarcity, inequity and declining returns: Exploring fresh approaches. The IWMI-Tata Water Policy Program, Seventh Annual Partners Meet, ICRISAT Campus, Hyderabad, 108-120.

[21] Narayanamoorthy, A. (2005) Economics of drip irrigation in sugarcane cultivation: Case study of a farmer from Tamil Nadu. Indian Journal of Agricultural Economics, 60, 235-248.

[22] Palanisami, K., Raman, S. and Mohan, K. (2012) Microirrigation Economics and Outreach. MacMillan Publishers India, New Delhi.

[23] John, M.A. and Flores, R. (2005) Impact evaluation of a conditional cash transfer program: The Nicaraguan Red de Social. Research Report 141, International Food Policy Research Institute, Washington DC.

[24] Pattanayak, K.S. (2009) Rough guide to impact evaluation of environmental and development program programs. Sandee Working Paper No.40-09, South Asian Network for Development and Environmental Economics, Nepal.

[25] Garrett, H.E. and Woodworth, R.S. (1973) Statistics in psychology and education. Vakils, Feffer and Simons Private Ltd, Bombay. 